\title{
Rekonseptualisasi Seleksi Hakim Konstitusi sebagai Upaya Mewujudkan Hakim Konstitusi yang Berkualifikasi
}

\author{
Indramayu \\ University of Jember, Indonesia \\ Indramayu.fh@gmail.com
}

\section{Jayus}

University of Jember, Indonesia

dr.jayus56.fh@unej.ac.id

\author{
Rosita Indrayati \\ University of Jember, Indonesia \\ rosita.indrayati@yahoo.com
}

\begin{abstract}
Integrity, good character, justice, and expert statesman of the constitution as the indicators to appoint Constitutional Judge should be taken into account by the Supreme Court, the House, and the President in the selection process. The cases of corruption named Akil Mochtar and Patrialis Akbar as the convicted and the suspected persons respectively should be regarded as an appropriate opportunity to evaluate law relating to the Constitutional Judges selection process in which it is not clearly defined in the Constitutional Court Act. To date, the law relating to selection is given to respective institutions where the Supreme Court takes the selection internally with no transparency, the House only requires to write and present article, and-in some cases-the President prefers to appoint with no adequate criteria. The article uses doctrinal research in addressing the case related to the current regulation on constitutional judge selection. It concludes that the Supreme Court, the House and the President ignore the principles of transparency, participatory, objectivity, and accountability in the selection, including the possibility of resulting unqualified judge. The selection needs reconceptualization comprising the establishment of expert panel, unaffiliated candidate to a political party, and reconcept of selection mechanism
\end{abstract}

KEYWORDS: Reconceptualization, Selection, Constitutional Judge.

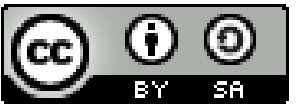

Copyright $\odot 2017$ by Author(s)

This work is licensed under a Creative Commons Attribution-ShareAlike 4.0 International License. All writings published in this journal are personal views of the authors and do not represent the views of this journal and the author's affiliated institutions.

\section{HOW TO CITE:}

Indramayu, Jayus \& Rosita Indrayati. "Rekonseptualisasi Seleksi Hakim Konstitusi sebagai Upaya Mewujudkan Hakim Konstitusi yang Berkualitas” (2017) 4:1 Lentera Hukum 1-18. 


\section{INTRODUCTION}

Mahkamah Konstitusi (MK) dibentuk melalui amandemen ketiga Undang-Undang Dasar Negara Republik Indonesia Tahun 1945 (UUD 1945) yang merupakan implikasi dari beralihnya kedaulatan MPR menjadi kedaulatan rakyat yang diimplementasikan melalui Undang-Undang Nomor 24 Tahun 2003 tentang Mahkamah Konstitusi (UU MK) beserta Undang-Undang Nomor 8 Tahun 2011 tentang Perubahan Atas UndangUndang Nomor 24 tahun 2003 tentang Mahkamah Konsitusi (UU MK Perubahan). ${ }^{1}$ Pembentukan MK merupakan koreksi terhadap pengalaman kehidupan ketatanegaraan di masa lalu yang ditimbulkan oleh tafsir ganda terhadap konstitusi. MK sebagai lembaga baru hasil reformasi bertugas untuk menangani perkara tertentu di bidang ketatanegaraan dalam rangka menjaga konstitusi agar dilaksanakan secara bertanggung jawab sesuai dengan kehendak rakyat dan cita-cita demokrasi.

Unsur utama yang mempengaruhi kemampuan MK dalam menjalankan tugasnya ditentukan oleh kualitas hakim konstitusi. ${ }^{2}$ Hakim konstitusi harus memiliki integritas, kepribadian yang baik, adil dan negarawan yang menguasai konstitusi. ${ }^{3}$ Persyaratan tersebut menjadi harapan dan kepercayaan besar dari masyarakat terhadap MK untuk menegakan hukum dan keadilan yang harus dijaga oleh hakim konstitusi sebagai aktor utama dalam menyelenggarakan peradilan di MK. Awal berdirinya MK juga ditandai dengan para hakim yang memiliki wawasan dan pengalaman yang luas dalam bidang konstitusi sehingga menghasilkan beragam terobosan guna mewujudkan keadilan konstitusional yang substantif, sehingga MK menjadi lembaga peradilan yang diandalkan oleh masyarakat untuk mendapatkan hak konstitusionalnya.

Indikator atas tingginya kepercayaan masyarakat kepada MK dapat dilihat dari banyak dan meningkatnya permohonan yang diajukan masyarakat kepada MK untuk diputus, khususnya dalam pengujian undang-undang terhadap Undang-Undang Dasar yang hampir tiapi tahun mengalami peningkatan sebagaimana dirinci sebagai berikut:

\footnotetext{
Djoko Imbawani, "Pengujian Peraturan Pemerintah Pengganti Undang-Undang oleh Mahkamah Konstitusi" (2014) 21:1 J Media Hukum, 15 hlm. 81.

2 Muchamad Ali Safa'at, Seminar Nasional: Pengisian dan Masa Jabatan Hakim Konstitusi (Universitas Jember, 2016), hlm. 1.

3 Persyaratan tersebut tercantum dalam Pasal 24C ayat (5) UUD 1945 jo Pasal 15 ayat (1) UU MK Perubahan. Peryaratan tersebut menjadi kualifikasi yang dijadikan pertimbangan utama dalam seleksi hakim konstitusi. Integritas bermakna mempuyai kepribadian utuh, tidak tergoyahkan yang terwujud pada sikap setia dan tangguh berpegang pada nilai-nilai atau norma-norma yang berlaku dalam melaksanakan tugas. Berkepribadian yang baik berarti memiliki etika baik dalam kehidupan sehari-hari yang akan mengantarkan menuju hakim konstitusi yang bermartabat. Adil dapat diartikan tidak berat sebelah, tidak memihak dan berpihak kepada yang benar. Keadilan menurut kajian filsafat adalah apabila dipenuhi dua prinsip yaitu tidak merugikan seseorang dan perlakuan kepada tiap-tiap manusia apa yang menjadi haknya. Jika kedua prinsip ini dapat dipenuhi oleh hakim barulah itu dikatakan sebagai hakim yang adil, sedangkan makna negarawan menurut Janedri M. Gaffar dapat diartikan sebagai sosok yang visioner, berorientasi jangka panjang, mengutamakan kesejahteraan masyarakat, mampu berlaku egaliter serta adil dan mengayomi semua komponen bangsa. Penguasaan konstitusi dapat diartikan bahwa hakim konstitusi harus memahami segala hal yang terkait dengan materi muatan konstitusi seperti cita-cita negara, struktur organisasi negara, serta hak asasi manusia dan hak konstitusional warga negara.
} 


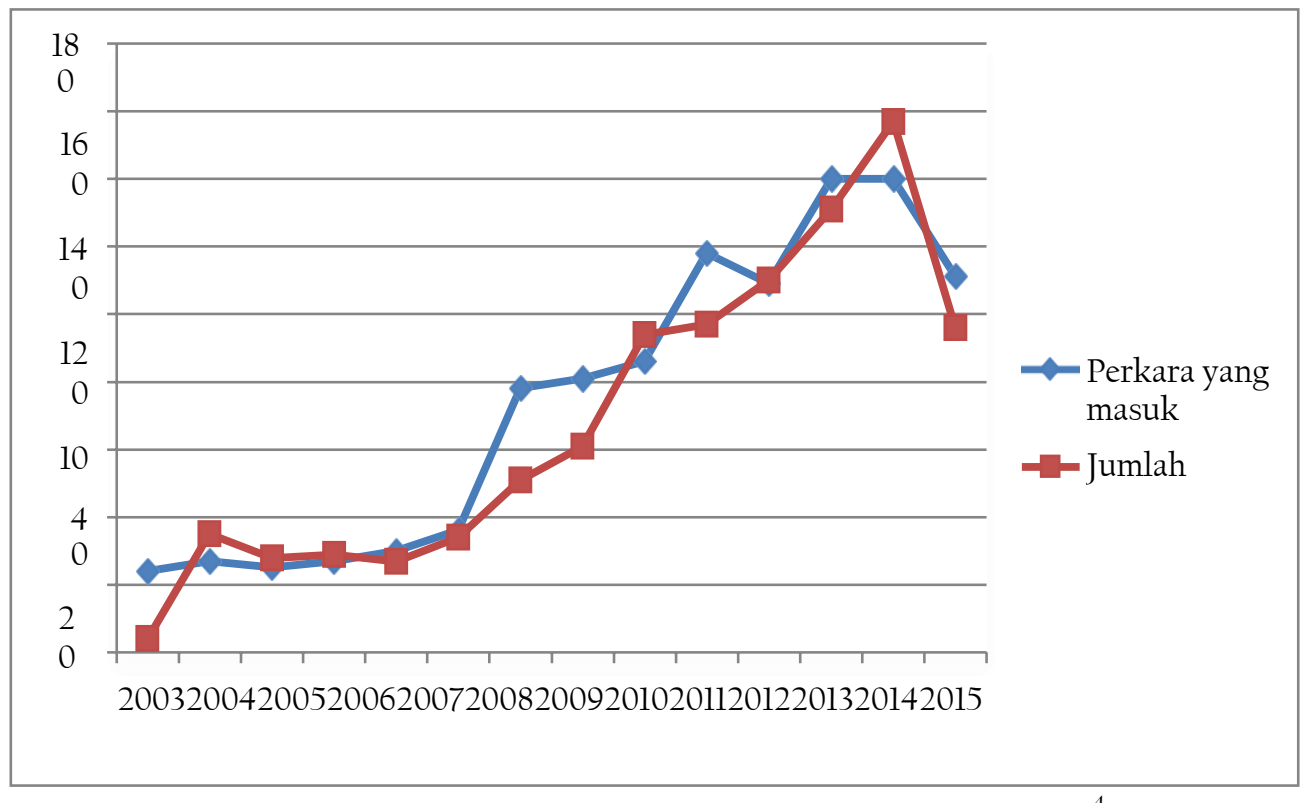

Sumber : Website resmi MK (www.mahkamahkonstitusi.go.id) ${ }^{4}$

Grafik 1 : Permohonan dan putusan pengujian UU terhadap UUD tahun 2003-2016

Grafik diatas menunjukan bahwa permohonan dan jumlah putusan pengujian UU terhadap UUD 1945 hampir setiap tahun mengalami kenaikan di mana selama 13 tahun (dari 2003 sampai 2016) hanya 3 tahun (2005, 2013 dan 2016) saja yang mengalami penurunan permohonan. Pada tahun 2005, permohonan pengujian mengalami sedikit penurunan dari 27 permohonan menjadi 25 permohonan, begitu juga pada tahun 2013 yang turun sebanyak 9 permohonan dari 118 menjadi 109 permohonan, padahal tahun 2006 sampai 2012 mengalami kenaikan secara terus menerus. Pada tahun 2014, permohonan mengalami kenaikan kembali dari 109 menjadi 140 permohonan yang menandakan bahwa MK masih mendapatkan kepercayaan dari masyarakat.

Disamping kepercayaan masyarakat terhadap MK, pada tahun 2014 MK justru mencederainya dengan terbongkarnya Akil Mochtar sebagai hakim konstitusi yang dinyatakan terbukti melakukan tindak pidana pencucian uang terkait kasus sengketa Pilkada di MK. ${ }^{5}$ Oleh karena itu, kepercayaan masyarakat pun menurun di mana sejak tahun 2015 hingga 2016 permohonan pengujian UU tidak lagi mengalami kenaikan, bahkan tahun 2016 mengalami penurunan 20,71\% yakni sebanyak 111 permohonan dari tahun sebelumnya yang mencapai 140 permohonan. Tidak hanya itu, Januari 2017 pun masyarakat dikagetkan dengan Operasi Tangkap Tangan (OTT) Patrialis Akbar oleh KPK yang diduga menerima suap terkait uji materi UU Peternakan dan Kesehatan Hewan. ${ }^{6}$ Kasus Akil Mochta dan Patrialis Akbar tersebut harus menjadi evaluasi

4 MK RI, "Rekapitulasi Perkara Pengujian Undang-Undang", online: 〈http://www.mahkamahkonstitusi.go.id/index.php?page=web.RekapPUU\&menu=5〉.

5 BBC, "Akil Mochtar divonis hukuman seumur hidup - BBC Indonesia", online: 〈http://www.bbc.com/indonesia/berita_indonesia/2014/06/140630_vonis_akil_muchtar〉.

6 Detiknews, "Suap untuk Patrialis Akbar Terkait Uji Materi UU Peternakan", online: 〈https:// news.detik.com/berita/3406297/suap-untuk-patrialis-akbar-terkait-uji-materi-uu-peternakan〉. 
terkait kualitas hakim konstitusi. Salah satu indikator yang dapat mempengaruhi kualitas hakim konstitusi adalah proses seleksi hakim konstitusi. ${ }^{7}$

UU MK tidak mengatur secara jelas mengenai seleksi hakim konstitusi, ${ }^{8}$ sehingga memberikan peluang bagi MA, DPR maupun Presiden sebagai lembaga pengusul hakim konstitusi untuk melaksanakan seleksi dengan persepsi sendiri. Konsekuensinya, proses seleksi diselenggarakan dengan ketentuan yang dibuat oleh masing-masing lembaga pengusul dengan mengesampingkan proses seleksi yang transparan, partisipatif, objektif dan akuntabel. Hingga saat ini, pelaksanaan seleksi hakim konstitusi oleh MA masih cenderung dilaksanakan secara tertutup dan bersifat internal, seperti pengajuan Suhartoyo dan Manahan MP Sitompul pada tahun 2014. Dalam proses seleksinya, MA mengesampingkan prinsip partisipasi masyarakat sehingga tidak banyak masyarakat mengetahui pelaksanaan seleksi calon hakim yang diselenggarakan oleh MA, sehingga MA mendapatkan kritikan dari Komisi Yudisial (KY) yang berisi bahwa proses seleksi tersebut pada tidak memenuhi syarat rekrutmen hakim konstitusi. ${ }^{9}$

Seleksi di DPR hanya sekedar pembuatan dan presentasi makalah dari calon hakim konstitusi, termasuk pada saat seleksi Akil Mochtar melalui komisi III DPR RI bidang hukum dan HAM. ${ }^{10}$ Pelaksanaan seleksi pada saat itu dilaksanakan secara tertutup dan tidak diinformasikan kepada publik terkait adanya seleksi hakim konstitusi. Selain dari MA dan DPR, seleksi oleh Presiden juga tidak kalah kontroversi karena pemilihan hakim konstitusi dilakukan secara penunjukan langsung, termasuk penunjukan Patrialis Akbar dan Maria Farida oleh Presiden Susilo Bambang Yudhoyono (SBY), bukan melalui mekanisme pemilihan yang merepresentasikan objektivitas. ${ }^{\text {ll }}$ Akibatnya, pelaksanaan seleksi hakim konstitusi oleh Presiden menurunkan kepercayaan publik terhadap pelaksanaan seleksi hakim konstitusi karena tidak dipenuhinya prinsip transparansi dan objektifitas dalam seleksi.

Uraian di atas menegaskan bahwa seleksi hakim konstitusi selama ini dapat dikatakan tidak transparan, partisipatif, objektif dan akuntabel sehingga melahir-kan hakim konstitusi yang tidak berkualifikasi. Berangkat dari permasalah ini perlu menjadi evaluasi dalam penyenggaraan seleksi hakim konstitusi di masa mendatang. Rekonseptualisasi seleksi hakim konstitusi diperlukan guna mewujud-kan hakim konstitusi yang berintegritas, berkepribadian baik, adil dan negarawan yang menguasai konstitusi.

\footnotetext{
Ahmad Fadlil Sumadi, "Independensi Mahkamah Konstitusi” (2011) 8 no. 5 J Konstitusi 632, hlm. 638. Pasal 20 ayat (1) UU MK menyebutkan bahwa ketentuan mengenai tata cara seleksi, pemilihan, dan pengajuan hakim konstitusi diatur oleh masing-masing lembaga yang berwenang yakni MA, DPR, dan Presiden. Akan tetapi, sampai saat ini belum ada pengaturan internal baik Perma, Peraturan Presiden, maupun Perpres yang mengatur terkait itu.

9 Tribunnews, "KY: Hakim MK dari MA Berpotensi Tak Penuhi Persyaratan", online: Tribunnews.com〈http://www.tribunnews.com/nasional/2014/12/03/ky-hakim-mk-dari-maberpotensi-tak-penuhi- persyaratan>.

10 Winda Wijayanti, Nuzul Quraini M \& Siswantana Putri R, "Transparansi dan Partisipasi Publik dalam Rekrutmen Calon Hakim Konstitusi” (2015) Vol. 12 No. 4 J. Konstitusi hlm. 673-674.

$11 \quad$ Ibid hlm. 674.
} 


\title{
II. REKONSEPTUALISASI SELEKSI HAKIM KONSTITUSI SEBAGAI UPAYA MEWUJUDKAN HAKIM KONSTITUSI YANG BERKUALIFIKASI
}

\begin{abstract}
A. Seleksi Hakim Konstitusi Selama Ini
Hakim konstitusi di Indonesia diajukan masing-masing 3 (tiga) orang oleh MA, DPR dan Presiden sebagaimana disebutkan dalam Pasal 24C UUD 1945 jo Pasal 18 ayat (1) UU MK. Pencalonan hakim konstitusi oleh lembaga pengaju harus dilaksanakan secara transparan dan partisipatif, ${ }^{12}$ sedangkan pemilihan hakim konstitusi harus memenuhi prinsip objektif dan akuntabel guna menghasilkan hakim konstitusi yang berkualifikasi. ${ }^{13}$ Akan tetapi dalam implementasinya, masing-masing lembaga pengaju mengesampingkan asas pencalonan dan pemilihan tersebut sehingga menimbulkan kontroversi di masyarakat.

Sejak dibentuknya MK, MA telah melaksanakan 6 kali pengisian hakim konstitusi. Pelaksanaan seleksi oleh MA dilaksanakan secara internal dan tertutup, seperti halnya seleksi hakim konstitusi periode terakhir pada tahun 2014 di mana pada saat itu dilaksanakan tanpa melakukan publikasi, masyarakat tidak mengetahui mekanisme seleksi yang dilakukan oleh MA, ${ }^{14}$ panitia seleksi dari internal MA serta pewawancara atau penilai tidak ada yang ahli konstitusi, ${ }^{15}$ sehingga terpilih Suhartoyo dan Manahan MP Sitompul yang masing-masing akan menggantikan Ahmad Fadlil Sumadi dan Muhammad Alim untuk periode 2015-2020, padahal Suhartoyo pada saat itu masih diselidiki oleh Komisi Yudisial ter-kait pelanggaran kode etik dalam pembebasan kasus BLBI Sudjiono Timan. ${ }^{16}$ Tidak hanya pada periode terakhir yang dilaksanakan secara tertutup, akan tetapi hampir disetiap periode juga demikian.

Pada periode pertama, MA mengajukan 3 orang hakim konstitusi perdana yakni Laica Marzuki, Soedarsono dan Maruarar Siahaan yang dilaksanakan secara tertutup dan internal, ${ }^{17}$ akan tetapi tidak membuat perhatian publik, karena masih adanya masa transisi dan desakan untuk segera merealisasikan MK. Meskipun dalam masa transisi,
\end{abstract}

12 Pasal 19 UU MK menyebutkan bahwa pencalonan hakim konstitusi dilaksanakan secara transparan dan partisifatif. Transparan dan partisipatif sebagaimana disebutkan dalam penjelasan pasal tersebut bahwa nama-nama calon hakim konstitusi yang telah mendaftarkan sebagai hakim konstitusi dipublikasikan di media massa, baik itu media cetak maupun elektronik, sehingga masyarakat dapat memberikan masukan kepada lembaga pengaju atas calon hakim konstitusi yang bersangkutan.

13 Pasal 20 ayat (2) UU MK Perubahan yang menyebutkan bahwa pemilihan hakim konstitusi dilaksanakan secara obyektif dan akuntabel. Objektif berarti dalam memilih hakim konstitusi harus sesuai dengan kompetensi yang dimiliki calon hakim konstitusi. Pemilihan tidak berdasarkan ras, golongan, agama dan lain sebagainya yang dapat mengakibatkan adanya perlakuan istimewa terhadap calon hakim konstitusi tertentu. Untuk menjaga objektifitas dalam pemilihan, maka diperlukan adanya suatu parameter yang menjadi pedoman baku dalam pelaksanaan seleksi calon hakim konstitusi. Prinsip obyektif dapat diimplementasikan dengan memberikan perlakuan yang sama terhadap setiap calon hakim konstitusi dalam pelaksanaan seleksi.

14 Tribunnews, supra note 9.

15 Ibid.

16 DetikNews, "Tanpa Seleksi yang Transparan, Hakim Konstitusi Anwar Usman Dipertanyakan”, online: 〈http://news.detik.com/berita/3182850/tanpa-seleksi-yang-transparan-hakim-konst itusianwar-usman-dipertanyakan>.

17 Winda Wijayanti, Nuzul Quraini M \& Siswantana Putri R, supra note 10, hlm. 666. 
akan tetapi tetap harus dilaksanakan secara transparan, partisipatif, objektif dan akuntabel. Selain itu, pada periode dua yakni pengajuan Arsyad Sanusi yang menggantikan Laica Marzuki, periode ketiga pengajuan Muhammad Alim yang menggantikan Soedarsono, periode keempat yakni pengajuan Ahmad Fadlil Sumadi yang menggantikan Maruarar dan periode kelima yaitu pengajuan Anwar Usman yang menggantikan M. Arsyad Sanusi pun dilaksanakan secara internal dan tertutup seperti halnya periode keenam. Dengan demikian, seleksi hakim konstitusi oleh MA dapat dikatakan tidak transparan, partisipatif, objektif dan akuntabel.

Selain itu, pelaksanaan seleksi di MA selama ini, hanya sebatas dari hakim agung atau hakim karir yang berada dibawah MA. ${ }^{18}$ Penulis sependapat dengan Bayu Dwi Anggono bahwa meskipun diajukan oleh MA, namun bukan berarti hakim konstitusi yang diajukan harus dari hakim agung dan hakim karir dibawah MA. ${ }^{19}$ Merujuk pada makna asli Pasal 24C ayat (3) UUD NRI Tahun 1945 adalah calon hakim konstitusi adalah warga negara Indonesia yang memenuhi persyaratan dan pengajuannya dilakukan melalui lembaga negara yang menunjuk-kan perimbangan kekuasaan yaitu eksekutif, legislatif dan yudikatif. ${ }^{20}$ Dengan demikian semua warga negara yang memenuhi kualifikasi berhak untuk mengajukan seleksi di MA, sehingga MA harus membuka peluang untuk warga negara diluar hakim agung dan hakim dibawah MA.

Sama halnya dengan pelaksanaan seleksi oleh MA, oleh Presiden pun menimbulkan banyak permasalahan. Presiden telah mengajukan beberapa kali periode pengisian hakim konstitusi. Pertama, pengangkatan hakim konstitusi perdana yakni Syarifudin, Mukthie Fadjar dan Harjono yang dilakukan secara tertutup oleh pemerintah, hingga sampai saat ini tidak diketahui publik mengenai pelaksanaan seleksi yang telah dilakukannya. ${ }^{21}$ Presiden mengangkat ketiga hakim konstitusi tersebut terkesan dipilih secara langsung dan tidak melibatkan masyarakat, sehingga tidak memenuhi prinsip yang telah ditentukan. Hal tersebut berbeda dengan seleksi pada periode kedua yakni pengangkatan Achmad Sodiki untuk menggantikan Syarifudin dan perpanjangan masa jabatan Mukhtie Fadjar yang dilaksanakan dengan pembentukan panitia seleksi yakni oleh Dewan Pertimbangan Presiden (Watimpres) yang diketuai oleh Adnan Buyung Nasution, ${ }^{22}$ namun Mukhtie Fadjar tidak melalui mekanisme seleksi melainkan langsung ditunjuk kembali. Hasil seleksi yang diadakan oleh panitia seleksi diumumkan ke publik, namun proses pencalonannya tidak dipublikasikan ke publik, padahal tahap pencalonan harus transparansi dan partisipatif, sehingga seleksi periode ini dapat dikatakan tidak memenuhi prinsip pencalonan.

Periode ketiga, SBY mengajukan Hamdan Zoelva untuk menggantikan Mukthie Fadjar atas usulan dari Kementerian Hukum dan $\mathrm{HAM}^{23}$ di mana seleksi dilaksanakan

18 Ibid, hlm. 666-669.

19 DetikNews, supra note hlm. 16.

20 Ibid.

${ }^{21}$ Winda Wijayanti, Nuzul Quraini M \& Siswantana Putri R, supra note $10 \mathrm{hlm} .667$.

22 Ibid hlm. 668.

23 Ibid hlm. 667. 
secara tertutup dan terkesan ditunjuk langsung. ${ }^{24}$ Pada periode ini dipenuhi dengan unsur politik karena hakim konstitusi yang diajukan berasal dari partai politik. Pada saat itu, Hamdan Zoelva menjabat sebagai wakil ketua umum Partai Bulan Bintang (PBB). ${ }^{25}$ Meskipun tidak ada persyaratan terkait keterlibatan calon dengan partai politik, akan tetapi sebagai lembaga yang independen seharusnya hakim konstitusi tidak memiliki afiliasi dengan partai politik, karena dapat mengganggu independensi hakim konstitusi dalam membuat putusan mengingat kewenangan MK yang berhubungan dengan kekuasaan politik, seperti menguji UU terhadap UUD 1945 yang tentu menentukan eksistensi DPR sebagai pembuat UU di mana DPR merupakan salah satu lembaga yang dibentuk dari hasil perpolitikan, juga kewenangan MK untuk membubarkan partai politik, tentu ikatan emosional antara hakim konstitusi dengan partai politik akan mempengaruhi putusan yang dihasilkan MK.

Pengangkatan hakim konstitusi yang memiliki ikatan dengan partai politik terulang kembali pada periode keempat. Pada periode ini, SBY secara terang-terangan melakukan penunjukan langsung Patrialis Akbar yang akan menggantikan Achmad Sodiki dan perpanjangan Maria Farida atas usulan kemeterian hukum dan HAM. ${ }^{26}$ Pada saat itu, Patrialis Akbar merupakan kader Partai Amanat Nasional (PAN). Masyarakat mempertanyakan kredibilitas Patrialis Akbar, karena dilihat dari rekam jejak (track record) nya bahwa Patrialis Akbar memiliki kinerja yang buruk. Ketidakberhasilannya terlihat dari sejumlah kebijakan/langkah Patrialis Akbar saat menjabat sebagai Menteri Hukum dan HAM yang kontroversial dan tidak sejalan dengan semangat pemberantasan korupsi, seperti obral remisi dan pembebasan bersyarat terhadap koruptor. ${ }^{27}$

Kekecewaan masyarakat atas pengangkatan langsung Patrialis Akbar dan Maria Farida terlihat ketika Koalisi Masyarakat Sipil Selamatkan MK mengajukan gugatan ke Pengadilan Tata Usaha Negara terkait Keputusan Presiden tentang penunjukan langsung Patrialis Akbar dan Maria Farida sebagaimana yang tertera dalam Keputusan Presiden Nomor 87 Tahun 2013, karena pelaksanaan seleksi tidak transparan, partisipatif, objektif dan akuntabel. ${ }^{28}$ Kekhawatiran masyarakat terkait kinerja Patrialis Akbar terbukti dengan kasus yang menimpa Patrialis Akbar. Pada awal tahun 2017 KPK melakukan Operasi Tangkap Tangan (OTT) terhadap Patrialis Akbar atas dugaan suap uji materi UU Peternakan dan Kesehatan Hewan. Berdasarkan hal di atas, dapat disimpulkan bahwa hanya periode kedua saja yang terdapat pelaksanaan seleksi.

24 Gresnews, "Penunjukan Tak Transparan, Ketua MK Hamdan Zoelva Ikut Digugat", online:http://www.gresnews.com/berita/hukum/1903112-penunjukan-tak-transparan-ketua-mkhamdan-zoelva-ikut-di-gugat/0/s.

25 Ibid.

26 Winda Wijayanti, Nuzul Quraini M \& Siswantana Putri R, supra note 10 hlm. 668-669.

27 Antikorupsi, "Patrialis Akbar Tidak Layak Menjadi Hakim Konstitusi | Indonesia Corruption Watch", online: 〈http:/www.antikorupsi.org/id/content/patrialis-akbar-tidak-layak-menjadi-hakimkonstitusi>.

28 Indonesia Corruption Watch (ICW), "Cabut Kepres yang Cacat Hukum dan Segera Seleksi Calon Hakim Mahkamah Konstitusi! | Indonesia Corruption Watch”, online: «/en/content/cabut-kepresyang-cacat-hukum-dan-segera-seleksi-calon-hakim-mahkamah-konstitusi>. 
Tentu hal tersebut dapat menurunkan kepercayaan masyarakat baik terhadap pelaksanaan seleksi oleh Presiden maupun terhadap MK.

Pelaksanaan seleksi hakim konstitusi di DPR, berbeda dengan di MA ataupun Presiden, karena di DPR pelaksanaan seleksinya lebih terbuka, akan tetapi tidak kalah kontroversinya karena di DPR kental dengan unsur politik. Selama ini, DPR telah melaksanakan 6 kali periode seleksi hakim konstitusi. Periode pertama, pengajuan 3 orang hakim perdana yaitu Jimly Asshiddiqie, I Dwa Gede Palguna dan Achmad Roestandi untuk masa jabatan 2003-2008 di mana seleksi dilaksanakan oleh Komisi II DPR RI dengan memberikan kesempatan bagi masyarakat untuk memberikan masukan terkait pengajuan nama-nama calon hakim konstitusi melalui fraksi di DPR dan dipublikasikan di media massa terkait pencalonan hakim konstitusi. Periode ini terdapat uji kepatutan dan kelayakan (fit and proper test), akan tetapi hanya sebatas pembuatan dan presentasi makalah di depan DPR dan dipilih secara voting oleh anggota DPR. ${ }^{29}$

Periode kedua, pengajuan Mahfud MD, Jimly Asshiddiqie dan H. M. Akil Mochtar untuk menggantikan Hakim Konstitusi sebelumnya untuk masa jabatan 2008-2013. Pada periode ini, Komisi III DPR membentuk tim kecil yang bertugas untuk melakukan seleksi administratif dan penentuan judul makalah. Kemudian tim kecil mengadakan pencalonan, sehingga terdapat 21 calon yang mendaftar. Dalam periode ini berbeda daripada periode I karena pencalonan tidak hanya pengajuan dari fraksi DPR namun juga dapat melalui jalur personal. Setelah seleksi administratif, maka calon hakim konstitusi yang lolos membuat makalah secara langsung dan mempresentasikannya dihadapan Komisi III DPR. Calon incumbent dalam periode ini tidak mengikuti uji kepatutan dan kelayakan. Setelah itu, calon hakim konstitusi dipilih melalui voting oleh DPR yang pada saat itu dihasilkan 3 orang calon hakim konstitusi yang akan diajukan yakni: Mahfud MD dengan 38 suara, Jimly Asshiddiqie memperoleh 37 suara dan H. M. Akil Mochtar dengan 32 suara. Hingga akhirnya ketiga calon terpilih tersebut ditetapkan oleh presiden sebagai hakim konstitusi. ${ }^{30}$

Periode ketiga, pengajuan Harjono menggantikan hakim konstitusi Jimly Asshiddiqie yang pada saat itu mengundurkan diri (masa jabatan 2009-2014). ${ }^{31}$ Pada periode ini, seleksi dilaksanakan oleh Komisi III DPR RI. DPR mengumumkan kepada publik melalui media cetak perihal pendaftaran calon hakim konstitusi, sehingga Komisi III DPR menerima 8 calon hakim konstitusi yang 4 calon diantara-nya pernah mengikuti uji kepatutan dan kelayakan di Komisi III DPR sehingga Komisi III DPR hanya mengadakan uji kepatutan dan kelayakan untuk 4 calon yang lainnya. DPR mengumumkan kepada publik terhadap calon-calon hakim konstitusi untuk mendapatkan masukan dan tanggapan dari masyarakat. Disamping itu, Calon hakim konstitusi membuat makalah secara langsung di hadapan Komisi III DPR dan mempresentasikannya serta dilengkapi dengam tanya-jawab terhadap calon hakim

29 Winda Wijayanti, Nuzul Quraini M \& Siswantana Putri R, supra note 10 hlm. 672.

30 Ibid hlm. 673-674.

31 Mahkamah Konstitusi, Jejak Langkah Satu Dasawarsa Mengawal Konstitusi Tahun 2003-2013 (Jakarta: Sekretariat Jenderal dan Kepaniteraan MK RI, 2015) hlm. 27. 
konstitusi, yang dilanjutkan dengan pemilihan 1 calon hakim konstitusi melalui cara pemungutan suara dan berdasarkan jumlah suara terbanyak dari masing-masing calon tersebut. ${ }^{32}$

Periode keempat, perpanjangan masa jabatan Akil Mochtar (masa jabatan 20132018). Pada periode ini tidak terdapat uji kelayakan melainkan proses yang singkat dan tertutup. DPR hanya menanyakan kepada Akil Mochtar atas kesediannya untuk menjabat kembali sebagai hakim konstitusi, sehingga pada periode ini DPR tidak melakukan kewajiban untuk melaksanakan seleksi dan melibatkan masyarakat untuk memberikan masukan terhadap nama calon hakim konstitusi dan kesempatan bagi masyarkat untuk mendaftarkan diri sebagai calon hakim konstitusi, serta tidak diumumkan secara terbuka bagi masyarakat. ${ }^{33}$

Periode kelima, pengajuan Arief Hidayat menggantikan hakim konstitusi Mahfud MD (masa jabatan 2013-2018). Pelaksanaan seleksi periode ini hampir sama dengan periode sebelumnya yaitu melalui Komisi III DPR. Komisi III DPR mengumumkan pencalonan ke media massa, sehingga terdapat 5 calon hakim konstitusi, namun dipertengahan jalan 3 calon hakim konstitusi mengundurkan diri sehingga hanya 2 calon hakim konstitusi yang melaksanakan uji kepatutan dan kelayakan berupa pembuatan makalah secara langsung di hadapan Komisi III DPR, setelah itu pemilihan dengan cara voting, sehingga terpilihlah Arief Hidayat dengan 42 suara yang mengalahkan Sugianto dengan 5 Suara dan Djafar Albram yang hanya memperoleh 1 suara. $^{34}$

Periode keenam, pengajuan Wahiduddin Adams dan Aswanto yang akan menggantikan Akil Mochtar dan Harjono (masa jabatan 2014-2019). Periode ini DPR membentuk Tim Pakar yang bertugas untuk melaksanakan uji kepatutan dan kelayakan berupa pemaparan makalah dan tanya jawab untuk memperdalam makalah yang dibuat, membuat rekomendasi nama-nama calon hakim konstitusi yang diserahkan kepada Komisi III DPR yang kemudian rekomendasi tersebut akan dijadikan sebagai bahan pertimbangan untuk menentukan calon hakim konstitusi. Setelah itu Komisi III DPR akan memilih hakim konstitusi atas rekomendasi dari dari Tim Pakar, sehingga terpilihlah Wahiduddin Adams dan Aswanto sebagai calon hakim konstitusi, yang mengalahkan 12 orang lainnya. ${ }^{35}$

Berdasarkan penjelasan pelaksanaan seleksi hakim konstitusi di masing-masing periode yang dilakukan oleh DPR, maka dapat disimpulkan terjadinya permasalahanpermasalahan mengenai pelaksanaan seleksi yang terjadi di DPR. Pelaksanaan seleksi dilakukan oleh Komisi III DPR, sehingga pelaksanaannya dipenuhi dengan unsur politis karena pada hakikatnya DPR dibentuk dari hasil perpolitikan, sehingga terkadang hakim konstitusi yang diajukan adalah hakim konstitusi yang berlatar belakang partai politik. Hal tersebut dapat dilihat dengan pengajuan Achmad

\footnotetext{
Winda Wijayanti, Nuzul Quraini M \& Siswantana Putri R, supra note $10 \mathrm{hlm} .675-676$.

Ibid hlm. 674 .

Ibid hlm. 677-678.

Ibid hlm. 677.
} 
Roestandi yang pada saat itu sebagai dewan penasehat PPP, hakim konstitusi Harjono dan I Dewa Gede yang pada saat itu merupakan kader PDIP, sehingga dikhawatirkan akan adanya unsur politik dalam putusan hakim konstitusinya.

Hakim konstitusi yang diajukan DPR berpotensi menghasilkan hakim konstitusi yang tidak berkualifikasi sebagaimana kualifikasi hakim konstitusi. Bagaimana bisa menilai penguasaan calon hakim konstitusi terhadap konstitusi apabila pelaksanaan seleksi hanya pembuatan dan presentasi makalah oleh calon hakim konstitusi. Hal tersebut dapat dilihat dari hakim konstitusi Akil Mochtar yang melakukan suap, korupsi dan pencucian uang terkait kasus sengketa Pilkada di MK.

Pelaksanaan seleksi di DPR, terkadang tidak memenuhi prinsip pencalonan dan pemilihan hakim konstitusi. Meskipun pelaksanaan seleksi di DPR lebih terbuka dan transparan daripada lembaga pengaju lainnya, akan tetapi masih ada kemungkinan DPR melaksanakan seleksi secara tertutup seperti halnya pada periode 3 yang dilaksanakan secara tertutup. DPR pun terkadang tidak melibatkan masyarakat dalam pelaksanaan seleksi, sehingga prinsip partisipasi dapat diragukan. Selain itu, karena terdapat unsur-unsur politis dalam seleksi, maka prinsip objektif dan akuntabel pun diragukan masyarakat.

Seleksi di DPR dilaksanakan oleh Komisi III DPR, hal ini pula jadi polemik di masyarakat pasalnya DPR belum tentu memahami konstitusi, mengingat untuk menjadi hakim konstitusi harus memahami konstitusi, maka yang menyeleksi pun sejatinya harus menguasainya. Pendidikan DPR minimal SLTA, padahal calon hakim konstitusi minimal S2. Seharusnya tidak dibenarkan seseorang yang berpendidikan rendah dapat menilai seseorang yang ber-pendidikan lebih tinggi darinya, hal ini tidak sesuai dengan tingkatan sistem pendidikan yang ada di Indonesia. Seharusnya yang menyeleksi memiliki kualifikasi minimal sama dengan subjek yang diseleksi.

Hasil survei yang dilakukan Setara Institute pada kesimpulan bahwa pola seleksi hakim konstitusi selama ini tidaklah tepat. Hakim konstitusi dipilih oleh tiga lembaga pemerintahan dimana dua di antaranya dianggap sangat politis, yakni DPR dan Presiden, para hakim konstitusi yang berlatar belakang dari kalangan politisi, potensi penyalahgunaan kewenangan oleh hakim konstitusi lebih besar, potensi kepentingankepentingan yang disisipkan pihak-pihak lain yang ada di balik hakim konstitusi dinilai sangat membahayakan integritas hakim hakim konstitusi, oleh karena itu sebanyak 61,5 persen responden menyatakan pola perekrutan yang dilakukan lembaga pengaju tidaklah tepat. ${ }^{36}$

Pelaksanaan seleksi hakim konstitusi di masing-masing lembaga pengaju berbeda-beda. Tanpa adanya keseragaman mekanisme yang diatur secara jelas oleh undang-undang justru akan menjadi celah bagi lembaga terkait untuk menggunakan mekanisme yang melanggar ketentuan dalam mengajukan hakim konstitusi. Standar

36 Rosita Indrayati, Rekonstruksi Proses Seleksi Hakim Konstitusi Melalui Perubahan Peraturan Perundang- undangan (2016) hlm. 19l. Sebagaimana dikutip dari Fatkhul Aziz, "200 ahli tata negara nyatakan rekrutmen hakim MK bermasalah", (11 November 2013), online: LensaIndonesia.com‘http://www.lensaindonesia. com/ 2013/11/11/200-ahli-tata-negara-nyatakanrekrutmen-hakim-mk-bermasalah.tml>. 
yang tidak jelas menjadi salah satu faktor diperolehnya hakim konstitusi yang memiliki kesenjangan dalam kualitasnya. Permasalahan-per-masalahan yang terjadi di masingmasing lembaga pengaju merupakan implikasi tidak adanya pengaturan yang jelas di UU MK mengenai pelaksanaan seleksi yang harus dilakukan oleh lembaga pengaju, sehingga memberikan peluang kepada masing-masing lembaga pengaju untuk melaksanakan seleksi dengan mengesampingkan prinsip pencalonan dan pemilihan serta kualifikasi hakim konstitusi yang harus dicapai. Kelemahan yang lainnya yaitu tidak ada ketentuan mengenai kriteria untuk menjadi panitia seleksi sebagai penguji calon hakim konstitusi, termasuk ketentuan mengenai keterlibatan partai politik dalam panitia seleksi. Hal tersebut memungkinkan adanya panitia seleksi yang berasal dari suatu partai politik tertentu yang akan berakibat terhadap dominasi partai politik dalam seleksi hakim konstitusi, apalagi DPR dan Presiden dibentuk melalui proses perpolitikan. Keterlibatan partai politik dalam panitia seleksi mengakibatkan terjadinya politisasi dalam pelaksanaan seleksi hakim konstitusi. Apabila permasalahan tersebut terus mengakar dalam pelaksanaan seleksi hakim konstitusi, maka dapat menggangu independensi hakim konstitusi dalam menjalakan tugasnya. Dengan demikian perlu rekonseptualisasi seleksi hakim konstitusi guna mewujudkan hakim konstitusi yang integritas, berkepribadian baik, adil dan negarawan yang menguasai konstitusi.

\section{B. Wujud Rekonseptualisasi Seleksi Hakim Konstitusi}

Wujud rekonseptualisasi seleksi hakim konstitusi meliputi pembentukan Panel Ahli, persyaratan tidak menjadi anggota partai politik bagi calon hakim konstitusi dan mengkonsep mekanisme seleksi. Penulis sepakat dengan pendapat Ali Safa'at bahwa konsep pelaksanaan seleksi harus diarahkan kepada penguatan independensi dan imparsialitas hakim konstitusi. ${ }^{37}$ Berkaitan dengan hal tersebut, hakim konstitusi harus independen yang tidak dapat diintervensi oleh lembaga dan kepentingan apapun, serta tidak memihak kepada salah satu pihak yang berperkara. ${ }^{38} \mathrm{Hal}$ paling potensial yang dapat mempengaruhi independensi hakim konstitusi adalah pengajuan hakim konstitusi, karena diajukan oleh lembaga lain. Lembaga peradilan yang tergantung pada lembaga lain dan tidak mampu mengatur dirinya secara mandiri akan menyebabkan sikap yang tidak netral dalam menjalankan tugasnya, ${ }^{39}$ termasuk hakim konstitusi. Hakim konstitusi yang diajukan merupakan pilihan masing-masing lembaga pengaju, dan dapat dimungkinkan bahwa lembaga pengaju akan mengajukan hakim konstitusi yang menguntungkan lembaga tersebut. Oleh karena itu, pelaksanaan seleksi harus dilaksanakan oleh pihak eksternal masing-masing lembaga pengaju.

Berdasarkan penjelasan diatas maka rekonseptualisasi pertama yakni pembentukan Panel ahli dalam melaksanakan seleksi hakim konstitusi. Widodo

37 Muchamad Ali Safa'at, supra note 2 hlm. 2.

38 Tim Penyusun Hukum Acara Mahkamah Konstitusi, Hukum acara Mahkamah Konstitusi, cet. 1. ed (Jakarta: Sekretariat Jenderal dan Kepaniteraan, Mahkamah Konstitusi, 2010) hlm. 18.

39 Titik Triwulan Tutik, "Pengawasan Hakim Konstitusi dalam Sistem Pengawasan Hakim Menurut Undang-Undang Dasar Negara RI 1945” (2012) 12:2 J Din Huk. 
Ekatjahjana menyatakan bahwa untuk menjadi penguji calon hakim konstitusi setidaknya sama kriterianya dengan calon hakim konstitusi. ${ }^{40}$ Hal tersebut merupakan hal yang wajar karena sudah semestinya pihak yang menguji harus lebih kredibilitas daripada pihak yang diuji. Mengingat bahwa hakim konstitusi harus memahami konstitusi, maka Panel Ahli pun harus dipersyaratkan untuk memahami konstitusi guna menilai apakah calon hakim konstitusi memahami konstitusi atau tidak. Selain itu, Panel Ahli harus dipersyaratkan minimal berpendidikan doktor guna mewujudkan akuntabilitas dalam seleksi, mengingat hakim konstitusi minimal berijazah magister, karena sejatinya pihak yang menguji harus memiliki pendidikan yang lebih tinggi daripada pihak yang diuji. Persyaratan tidak memiliki afiliasi dengan partai politik juga merupakan keharusan guna menjamin objektifitas dalam pelaksanaan seleksi. Jika tidak dipersyaratkan demikian maka dikhawatirkan akan adanya unsur politik yang akan mencederai prinsip objektif dalam pelaksanaan seleksi hakim konstitusi di masing-masing lembaga pengaju.

Wujud rekonseptualisasi yang kedua yakni penambahan persyaratan hakim konstitusi. Mengingat kewenangan MK yang mempengaruhi eksistensi lembaga politik $^{41}$ yakni DPR sebagai pembentuk undang-undang pada perkara pengujian undang-undang terhadap UUD, semua lembaga negara dalam perkara sengketa kewenangan lembaga negara serta partai politik pada perkara perselisihan hasil pemilu dan pembubaran partai politik. Selama ini, hakim konstitusi tidak ada persyaratan keanggotaan partai politik, sehingga riskan adanya unsur politik dan menganggu independensi hakim konstitusi dalam memutus sengketa, hal tersebut terbukti dengan kasus suap hakim konstitusi yang berlatar belakang partai politik. Hakim tidak dapat diharapkan bersikap netral dalam menjalankan tugasnya apabila tidak independen. ${ }^{42}$ Oleh karena itu, jaminan independensi hakim konstitusi terhadap partai politik melalui persyaratan tidak menjadi anggota partai politik sudah pada tempatnya untuk diberlakukan.

Rekonseptualisasi yang ketiga yakni terkait mekanisme seleksi hakim konstitusi yang harus diarahkan untuk meningkatkan legitimasi publik terhadap MK di mana MK harus tampil sebagai lembaga peradilan harapan masyarakat. Sebagai negara demokrasi, kekuasaan diperoleh dari sumbangsi masyarakat, maka menjadi hal yang penting bagi hakim konstitusi untuk mendapatkan kepercayaan dari masyarakat sebagai salah satu pendukung terwujudnya MK yang bermartabat melalui pelaksanaan seleksi yang transparan, partisipatif, objektif dan akuntabel. Integritas, memiliki kepribadian yang baik, adil, dan negarawan yang menguasai konstitusi sebagai indikator dalam menentukan hakim konstitusi harus menjadi pertimbangan utama dalam seleksi calon hakim konstitusi

Mekanisme seleksi disusun dengan tiga tahapan, yakni tahapan persiapan, tahapan seleksi dan tahapan pascaseleksi. Pada tahapan persiapan, masing-masing

\footnotetext{
40 Putusan Mahkamah Konstitusi nomor 1-2/PUU-XII/2014, Mahkamah Konstitusi, 2014 [Putusan Mahkamah Konstitusi nomor 1-2/PUU-XII/2014].

41 Muchamad Ali Safa'at, supra note $2 \mathrm{hlm}$. 5.

42 TriwulanTutik, supra note 39 hlm. 299.
} 
lembaga pengaju membentukan Panel Ahli sebagai panitia seleksi dengan memperhatikan persyaratan yang telah ditentukan. Setelah Panel Ahli terbentuk, Panel Ahli melakukan publikasi melalui media massa baik cetak maupun elektronik terkait akan diadakannya seleksi hakim konstitusi. Tidak hanya mengenai pendaftaran calon hakim konstitusi, tetapi Panel Ahli juga berkewajiban untuk mempublikasikan namanama calon hakim konstitusi, sehingga masyarakat dapat mengetahui calon-calon yang dapat melanjutnya ke seleksi tahap selanjutnya. Panel Ahli dapat membuat suatu website sebagai media untuk transparansi kepada masyarakat.

Peserta seleksi tidak hanya yang mendaftarkan diri akan tetapi masyarakat dapat merekomendasikan seseorang untuk mendaftarkan sebagai calon hakim konstitusi. Seleksi pertama yakni seleksi Administrasi, dimana pada tahapan ini seluruh pendaftar harus memenuhi dan menyerahkan kelengkapan administrasi sebagaimana ketentuan dalam Pasal 15 ayat (2) dan (3) UU MK Perubahan. ${ }^{43}$ Dalam seleksi adminitratif, Panel Ahli harus melakukan verifikasi kebenaran dokumen yang telah diserahkan oleh calon hakim konstitusi. Apabila Panel Ahli menemukan kecurangan administratif yang dilakukan peserta, maka Panel Ahli dapat menggugurkan kepesertaanya.

Mengingat bahwa hakim konstitusi yang negarawan dan menguasai konstitusi yang merupakan salah satu indikator penting dalam menentukan hakim konstitusi, maka diperlukan tahapan seleksi yang untuk menilai negarawan dan pemahaman konstitusi. Meskipun makna negarawan belum dapat dideskripsikan secara spesifik dalam peraturan perundang-undangan, akan tetapi secara gramatikal adalah orang yang memiliki pengetahuan dan keahlian penyelenggara-an negara, dan pengalaman yang cukup, serta komitmen untuk melaksanakan dan mengawal kehidupan bernegara sesuai dengan koridor konstitusi. ${ }^{44}$ Kualitas penguasaan konstitusi dapat diukur dari tingkat pendidikan, pengalaman kerja serta pengujiannya baik tulisan maupun lisan. ${ }^{45}$ Dengan demikian, seleksi akademis yang terdiri dari test Psikologi, tes tertulis mengenai pemahaman konstitusi, pembuatan dan presentasi makalah akan dihadapi oleh calon hakim konstitusi yang dinyatakan lolos seleksi administratif.

Setelah itu, calon hakim konstitusi akan melaksanakan seleksi praktek persidangan semu sederhana (small moot court) guna menilai pemahaman konstitusi, penguasaan dalam beracara di MK, dan pemahaman menganalisis perkara dengan batu uji konstitusi sehingga diharapkan akan melahirkan hakim konstitusi yang negarawan dan menguasai konstitusi. Calon hakim konstitusi akan

43 Pasal 15 ayat (2) menyebutkan bahwa calon hakim konstitusi harus WNI, berijazah minimal magister dibidang hukum, bertakwa kepada Tuhan Yang Maha Esa, berahlak mulia, berusia paling rendah 47 tahun dan paling tinggi 65 tahun pada saat pengangkatan pertama, sehat jasmani dan rohani, tidak pernah dijatuhi pidan penjara, tidak sedang dinyatakan pailit oleh pengadilan, dan memiliki pengalaman kerja dibidang hukum minimal 15 tahun dan/atau pernah menjadi penjabat negara. Selain itu, dalam ayat (3)nya disebutkan bahwa hakim konstitusi harus memenuhi kelengkapan administrasi yakni : Surat kesediaan menjadi hakim konstitusi, daftar riwayat hidup, legalisir ijazah, laporan daftar harta kekayaan dan sumber penghasilan serta nomor pokok wajib pajak (NPWP).

44 Janedjri M Gaffar, "Hakim Konstitusi dan Negarawan | Mahkamah Konstitusi Republik Indonesia", online: 〈http://www.mahkamahkonstitusi.go.id/index.php?page=web. Berita\&sid=11780\#.WNB6GhKzYvJ>.

45 Muchamad Ali Safa'at, supra note $2 \mathrm{hlm}$. 3. 
dihadapkan dengan judicial review suatu perkara yang telah disediakan oleh Panel Ahli di mana semua elemen dalam persidangan telah direkayasa dan dipersiapkan oleh Panel Ahli. Calon hakim konstitusi akan membuat putusan atau pendapat hukum dari kasus yang telah ditentukan oleh Panel Ahli. Dengan demikian, Panel Ahli dapat melihat tentang bagaimana calon hakim konstitusi membuat pertimbangan hukum, memutus perkara, penguasaan diri dalam berperkara di persidangan, menilai integritas calon hakim konstitusi serta menilai pemahaman konstitusi dari putusan atau pendapat hukum yang telah dibuat oleh Panel Ahli.

Calon hakim konstitusi juga akan dihadapkan dalam kondisi permusyawarat-an hakim konstitusi untuk mengeluarkan putusan. Calon hakim konstitusi juga akan dibentuk kelompok untuk melakukan permusyawaratan hakim konstitusi dalam memutus suatu perkara yang telah disediakan oleh panel ahli guna mengetahui kerja sama tim calon hakim konstitusi dalam menjatuhkan putusan. Setelah calon hakim konstitusi melalui keseluruhan seleksi tahap ini, selanjutnya Panel Ahli akan menentukan calon hakim konstitusi yang memenuhi syarat negarawan yang menguasai konstitusi dan akan melanjutkan ke seleksi berikutnya.

Selain itu, Integritas, berkepribadian baik dan adil yang merupakan indikator dalam menentukan hakim konstitusi di mana hal tersebut tidak dapat diukur dalam waktu tertentu saja, melainkan dalam jangka waktu yang lama karena Integritas, berkepribadian baik dan adil merupakan sifat personal dari masing-masing calon hakim konstitusi yang tumbuh dan berkembang sepanjang kehidupannya. Sifat dan karakter tersebut hanya dapat dilihat dari rekam jejak dan penilaian dari masyarakat terkait calon hakim konstitusi. ${ }^{46}$ Dengan demikian, seleksi selanjutnya Panel Ahli akan melakukan penilaian terkait rekam jejak calon hakim konstitusi dan menampung masukan dari masyarakat melalui seleksi dengar pendapat (public hearing). Panel Ahli harus berperan aktif untuk menggali informasi mengenai rekam jejak calon hakim konstitusi melalui berkordinasi dengan lembaga lain dan masyarkat pada umumnya yang memiliki keterkaitan dengan rekam jejak calon hakim konstitusi di mana hal tersebut akan menjadi pertimbangan Panel Ahli dalam memilih hakim konstitusi.

Selain itu, Panel Ahli melakukan koordinasi langsung dengan Komisi Pemberantasan Korupsi (KPK) dan Pusat Pelaporan Analisis Transaksi Keuangan (PPATK) untuk mengetahui dan menelusuri harta kekayaan calon hakim konstitusi yang akan dijadikan pertimbangan dalam memilih. Selain itu, Panel Ahli melakukan dengar pendapat kepada masyarakat melalui elemen-elemen masyarakat yang dalam hal ini organisasi masyarakat, lembaga swadaya masyarakat, tokoh masyarakat dan/atau masyarakat pada umumnya guna mewujudkan seleksi yang partisipatif. Dengar pendapat ini dilakukan dengan dialog dan diskusi di mana calon hakim konstitusi dihadapkan secara langsung dengan berbagai elemen masyarakat tersebut untuk kemudian saling melakukan proses tanya jawab dan saling memberikan masukan-masukan demi kemajuan MK kedepannya. 
Panel Ahli akan memilih calon hakim konstitusi yang memenuhi kualifikasi melalui musyawarah Panel Ahli dengan mempertimbangkan segala aspek penilaian. Kemudian Panel Ahli akan membuat keputusan Panel Ahli mengenai calon hakim konstitusi yang memenuhi kualifikasi. Setelah itu, Panel Ahli akan mempresentasikan keputusan Panel Ahli didepan lembaga pengaju terkait pelaksanaan seleksi dan kualitas masing-masing calon hakim konstitusi yang telah dinyatakan berkualifikasi, sehingga Panel Ahli dan lembaga pengaju memilih calon hakim konstitusi terbaik yang akan diserahkan kepada Presiden untuk diangkat menjadi hakim konstitusi melalui keputusan Presiden, sehingga terpilihnya hakim konstitusi yang memenuhi kualifikasi.

Proses seleksi ketiga yakni setelah seleksi di mana Panel Ahli harus membuat dan menyerahkan pertanggungjawaban secara tertulis kepada lembaga pengaju sebagai wujud pelaksanaan seleksi yang akuntabel. Penyerahan pertanggung-jawaban diserahkan setelah pelaksanaan musyawarah bersama antara Panel Ahli dengan masing-masing lembaga pengaju. Setelah itu, masing-masing lembaga pengaju akan mengajukan hakim konstitusi terpilih kepada presiden untuk ditetapkan dan dilantik melalui Keputusan Presiden. Dengan demikian, pelaksana-an seleksi sesuai dengan prinsip transparan, partisipatif, objektif dan akuntabel guna mewujudkan hakim konstitusi yang integritas, berkepribadian baik, adil dan negarawan yang menguasai konstitusi.

Konsep seleksi hakim konstitusi yang telah diuraikan perlu diatur dalam peraturan perundang-undangan guna menjamin kepastian hukum, karena dalam setiap negara hukum dipersyaratkan berlakunya asas legalitas (due process of law) yaitu segala tindakan pemerintahan harus didasarkan atas peraturan perundang-undangan yang sah dan tertulis. ${ }^{47}$ Oleh karena itu, pemerintah harus merevisi UU MK beserta peraturan pelaksananya dengan mengakomodasi gagasan penulis.

\section{KESIMPULAN}

Kasus suap Akil Mochtar dan Patrialis Akbar menjadi pembelajaran penting bagi Indonesia, terutama terkait dengan sistem seleksi hakim konstitusi yang tidak diatur secara jelas dalam peraturan perundang-undangan di mana UU MK hanya mengatur bahwa ketentuan mekanisme seleksi diatur oleh masing-masing lembaga pengusul. Selama ini, MA menyeleksi secara internal yang tidak transparan, DPR hanya pembuatan dan presentasi makalah, dan Presiden lebih menyukai cara penunjukan langsung tanpa kriteria yang cukup dan dipenuhi unsur politk. Prinsip transparan, partisipatif, objektif dan akuntabel dapat dikatakan tidak nampak dalam seleksi, begitu juga terkait dengan integritas, kepribadian baik, adil dan negarawan yang menguasai konstitusi masih belum tampak menjadi ukuran utama dalam proses seleksi hakim konstitusi. Menyikapi hal tersebut, diperlukan agenda rekonseptualisasi seleksi hakim konstitusi guna mewujudkan hakim konstitusi yang berkualifikasi.

47 Martitah, Mahkamah Konstitusi, dari Negative Legislature ke Positive Legislature?, cetakan 1 ed (Jakarta: Konstitusi Press, 2013) hlm. 32. 
Rekonseptualisasi seleksi hakim konstitusi meliputi pembentukan Panel Ahli, persyaratan tidak menjadi anggota partai politik bagi calon hakim konstitusi, dan mengkonsep mekanisme seleksi hakim konstitusi. Panel Ahli merupakan panitia seleksi yang dibentuk oleh masing-masing lembaga pengaju, di mana Panel Ahli harus berijazah doctor yang menguasai konstitusi dan tidak menjadi anggota partai politik. Penambahan persyaratan tidak menjadi anggota partai politik bagi calon hakim konstitusi guna menjaga independensi hakim konstitusi. Mekanisme seleksi calon hakim konstitusi harus diarahkan pada tercapainya hakim konstitusi yang berintegritas, berkeperibadian yang baik, adil dan negarawan yang menguasai konstitusi melalui beberapa tahapan seleksi.

Mekanisme seleksi disusun dengan tiga tahapan yang terdiri dari persiapan seleksi, pelaksanaan seleksi dan pascaseleksi. Pada tahapan persiapan, masing-masing lembaga pengaju mempersiapkan segala hal yang dibutuhkan dalam pelaksanaan seleksi termasuk pembentukan Panel Ahli. Setelah Panel Ahli terbentuk, Panel Ahli melakukan publikasi melalui media massa baik cetak maupun elektronik terkait akan diadakannya seleksi hakim konstitusi. Pelaksanaan seleksi terdiri dari seleksi administratif di mana calon hakim konstitusi menyerahkan persyaratan administrasi yang diatur dalam UU MK, seleksi Akademis di mana calon hakim konstitusi akan diuji mengenai pemahaman konstitusinya melalui pembuatan makalah dan presentasinya serta praktek persidangan semu sederhana. Selain itu, Panel Ahli akan menelusuri rekam jejak masing-masing calon hakim konstitusi yang melibatkan KPK dan PPATK guna menelusuri harta kekayaan calon hakim konstitusi dan pelibatan organisasi masyarakat, LSM dan/atau masyarakat guna memberikan pertimbangan-pertimbangan dalam memilih hakim konstitusi.

Panel Ahli akan mengadakan musyawarah Panel Ahli untuk menentukan calon hakim konstitusi yang memenuhi kualifikasi, setelah itu Panel Ahli akan melakukan musyawarah bersama dengan masing-masing lembaga pengaju untuk menentukan calon hakim konstitusi yang akan diajukan, sehingga terpilihlah calon hakim konstitusi terbaik yang akan diajukan kepada presiden untuk dilantik. Tahapan ketiga yakni tahapan pascaseleksi di mana Panel Ahli membuat laporan pertanggungjawaban guna mewujudkan seleksi hakim konstitusi yang akuntabel.

\section{DAFTAR PUSTAKA}

Ahmad Fadlil Sumadi, "Independensi Mahkamah Konstitusi" (2011) 8 no. 5 J Konstitusi.

Antikorupsi, "Patrialis Akbar Tidak Layak Menjadi Hakim Konstitusi | Indonesia Corruption Watch", online: 〈http://www.antikorupsi.org/id/ content/patrialisakbar-tidak-layak-menjadi-hakim-konstitusi>.

BBC, "Akil Mochtar divonis hukuman seumur hidup - BBC Indonesia", online: 〈http://www.bbc.com/indonesia/berita_indonesia/2014/06/140630_vonis_akil_mu chtar». 
Detiknews, "Suap untuk Patrialis Akbar Terkait Uji Materi UU Peternakan”, online: 〈https://news.detik.com/berita/3406297/suap-untuk-patrialis-akbar-terkait-ujimateri-uu-peternakan>.

DetikNews, "Tanpa Seleksi yang Transparan, Hakim Konstitusi Anwar Usman Dipertanyakan”, online: 〈http://news.detik.com/berita/3182850/tanpa-seleksiyang-transparan-hakim-konst itusi-anwar-usman-dipertanyakan>.

Djoko Imbawani, "Pengujian Peraturan Pemerintah Pengganti Undang-Undang oleh Mahkamah Konstitusi" (2014) 21:1 J Media Hukum

Fatkhul Aziz, "200 ahli tata negara nyatakan rekrutmen hakim MK bermasalah", (1l November 2013), online: LensaIndonesia.com 〈http://www.lensaindonesia.com/ 2013/11/11/200-ahli-tata-negara-nyatakanrekrutmen-hakim-mk-bermasalah.tml>.

Gresnews, "Penunjukan Tak Transparan, Ketua MK Hamdan Zoelva Ikut Digugat",online: 〈http:/www.gresnews.com/berita/hukum/1903112penunjukan-tak-transparan-ketua-mk-hamdan-zoelva-ikut-di-gugat/0/>.

Indonesia Corruption Watch (ICW), "Cabut Kepres yang Cacat Hukum dan Segera Seleksi Calon Hakim Mahkamah Konstitusi! | Indonesia Corruption Watch", online: </en/content/cabut-kepres-yang-cacat-hukum-dan-segera-seleksi-calonhakim-mahkamah-konstitusi>.

Janedjri M Gaffar, "Hakim Konstitusi dan Negarawan | Mahkamah Konstitusi Republik Indonesia”, online: 〈http://www.mahkamahkonstitusi.go.id/index.php? page=web. Berita\&¿id=11780\#.WNB6GhKzYvJ〉.

Mahkamah Konstitusi, Jejak Langkah Satu Dasawarsa Mengawal Konstitusi Tahun 2003-2013

(Jakarta: Sekretariat Jenderal dan Kepaniteraan MK RI, 2015).

Martitah, Mahkamah Konstitusi, dari Negative Legislature ke Positive Legislature?, cetakan 1 ed (Jakarta: Konstitusi Press, 2013).

MK RI, "Rekapitulasi Perkara Pengujian Undang-Undang", online:

〈http://www.mahkamahkonstitusi.go.id/index.php?page=web.RekapPUU\& \&menu $=5$.

Muchamad Ali Safa'at, Seminar Nasional: Pengisian dan Masa Jabatan Hakim Konstitusi

(Jember: Universitas Jember, 2016).

Penyusun Hukum Acara Mahkamah Konstitusi, Hukum acara Mahkamah Konstitusi, cet. 1. ed (Jakarta: Sekretariat Jenderal dan Kepaniteraan, Mahkamah Konstitusi, 2010).

Titik Triwulan Tutik, "Pengawasan Hakim Konstitusi dalam Sistem Pengawasan Hakim Menurut Undang-Undang Dasar Negara RI 1945” (2012) 12:2 J Din Huk.

Tribunnews, "KY: Hakim MK dari MA Berpotensi Tak Penuhi Persyaratan", online: Tribunnews.com 〈http://www.tribunnews.com/nasional/2014/ 12/03/ky-hakimmk-dari-ma-berpotensi-tak-penuhi-persyaratan〉. 
18 | Rekonseptualisasi Seleksi Hakim Konstitusi sebagai Upaya Mewujudkan Hakim Konstitusi yang Berkualitas

Winda Wijayanti, Nuzul Quraini M \& Siswantana Putri R, "Transparansi dan Partisipasi Publik dalam Rekrutmen Calon Hakim Konstitusi” (2015) Vol. 12 No. 4 J. Konstitusi 